УДК 930.85:17.023.36

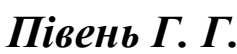

doi: 10.32620/gch.2019.2.04

\title{
«ПАСТИР ДОБРИЙ»: СУСПІЛЬНИЙ ПРОЕКТ МЕЛЕТІЯ СМОТРИЦЬКОГО
}

Статтю присвячено розгляду сочіально-політичних ідей Мелетія Смотрицького, поданих у його трактаті «Тренос». Проаналізовано погляди автора на роль $i$ місие православної ієрархії у формуванні украӥнської начіональної ідеології в ранньомодерну добу.

Ключові слова: православна ієрархія, иерковна еліта, пастир, моральна досконалість.

The article considers social and political ideas of Meletius Smotrytsky, which were presented in his treatise "Threnos". The views of the author on the role and place of the Orthodox hierarchy in the formation of Ukrainian national ideology in the early modern era have been analyzed.

Keywords: orthodox hierarchy, church elite, shepherd, moral perfection.

Дослідження творчого доробку Мелетія Смотрицького набуває нової актуальності в сучасних умовах активізації політичної свідомості суспільства, а також підвищення інтересу до проблем національної, релігійної та політичної ідентичності. Масштабність його мислення й різноманітність висвітлених ним проблем зумовили увагу до його творчості з боку істориків, філологів, культурологів, філософів, правознавців тощо. Але, оскільки метою цієї статті $\epsilon$ аналіз поглядів М. Смотрицького на роль і місце православної ієрархії у формуванні української національної ідеології та політичної культури в його програмному трактаті «Тренос», варто зупинитися на тих дослідженнях, які характеризують М. Смотрицького як соціально-політичного мислителя й аналізують його життєвий і творчий шлях 3 цієї позиції. Можна виділити монографії С. Бабича [1] та П. Кралюка [4], колективну роботу П. Кралюка, В. Щепанского, М. Якубовича [5], наукові публікації Л. Квасюка [3], I. Майданюк [6], О. Неменського [8], М. Сенети [12]. Проблематика уявлень православного духовенства про державний устрій також розглядалася такими науковцями, як С. Мицик [7], С. Плохій [10], Н. Яковенко [15] та ін. Зокрема, ідеї М. Смотрицького про державу були докладно розглянуті у статті Н. Шалашної [14]. Проте окремим предметом дослідження погляди М. Смотрицького на процес формування української національної ідеології та політичної традиції, висловлені у його «Треносі», досі не були.

У 1610 р. у друкарні Віленського братства була надрукована книга «Тренос, або плач східної церкви», автором якої був Мелетій Смотрицький, що укрився під псевдонімом Теофіл Ортолог. Уже сучасники високо оцінили цей шедевр православної полемічної літератури й визнали іiї книгою пророчою, у святості рівною Свангелію, порівнюючи іï автора 3 Іоанном Златоустом. [16, с. 50]. На адресу «Треносу» авторитетний діяч Острозької академії Дем'ян Наливайко висловився так: «За важливістю описаної в ньому правди божої рівний писанням Златоуста; за нього 
кров свою пролити i душі покласти нам годиться» [18, с. 7]. Пізніше сам М. Смотрицький писав, що в цей період був «славою, ласкою, милістю народу мого аж під небо піднесений» [18, с. 22].

Така захоплена реакція українського суспільства не здається надмірною, якщо врахувати, у який історично складний період вона була написана і вирішенню яких проблем присвячена. На момент виходу книги основою внутрішньої політики Речі Посполитої щодо українців стало послідовне втілення в життя принципу, що був запропонований у 1590 р. відомим ідеологом Контрреформації П. Скаргою в передмові до другого видання своєї книги «Про єдність церкви божої»: єдність держави можлива тільки на основі єдності церковної [9, с. 527; 529-530]. Ця політика передбачала необхідність завдати удару по зримому прояву автономних прав українців - православній церкві, в умовах, коли конфесійна орієнтація відігравала більш значну роль у визначенні національної приналежності, ніж власне походження [11, с. 97-98]. Наслідком Контрреформації для українців стала втрата рівноправного національного статусу стосовно решти націй в Речі Посполитої, а православна церква більше не сприймалася як репрезентант національної культури й ідеологічна опора держави, ієрархи якої були уособленням морального закону в суспільстві. У 1596 р. православні ієрархи фактично були вимушені запропонувати польському уряду варіант угоди, яка б повернула православній церкві статус державної, а 3 ним і культурно-політичний вплив у суспільстві - Брестську унію [2, с. 99]. Але тиск із боку Риму, який намагався повністю підпорядкувати Київську церкву, ускладнив це рішення, яке спочатку припускало тільки зміну юрисдикції (Рим замість Константинополя). Унія зустріла активний опір православної громадськості, що розцінила ï як акт духовної зради й не визнала уніатську ієрархію легітимною. У результаті на початку XVII ст. українці фактично втратили свою церковну еліту.

Трактат М. Смотрицького, а точніше, його перші чотири розділи, у яких викладено основний ідейний зміст книги, має дві основних мети: перша - констатація катастрофічного становища української православної церкви й усього українського суспільства в цілому, а також аналіз причин цієї національної трагедії; друга своєрідна політична декларація, що пропонує програму з подолання іiі наслідків, альтернативну унії, яка й знайшла широке підтримання української православної громадськості. Поставленої мети полеміст досягає, використовуючи своєрідний літературний прийом, який можна умовно охарактеризувати як протиставлення двох образів пастиря - реального земного «пастиря злого» й очікуваного ідеального «пастиря доброго».

Ключовою ідеєю автора «Треносу» є думка, що сучасні йому суспільно-історичні умови вимагають появи в Україні плеяди вождів-пророків, духовних наставників народу, рівних «докторам» і «апостолам» перших століть християнства [13, с. 70]. Їхнє завдання - просвітити українське суспільство й піднести його національнорелігійну свідомість. Якщо взяти до уваги значення, яке автор «Треносу» приділяє критиці ієрархів української православної церкви, коли визначає їхню роль у суспільстві, яку співвідносить 3 очікуваним приходом таких духовних вождів, $\epsilon$ всі підстави припустити, що висунути їх повинна саме церква. Вона ж мислиться 
Смотрицьким як авторитетний соціальний інститут, зобов'язаний стати опорою для морального оздоровлення суспільства і його консолідації перед обличчям зовнішньої загрози.

У цьому зв'язку окреме місце М. Смотрицький відводить осуду дійсних винуватців становища, що створилося - церковних ієрархів. Образ «пастиря злого» в «Треносі» полеміст малює, використовуючи навмисно темні фарби. Він виділяє три основних рівня критики, за якими судить про ступінь занепаду пастиря, богословський, етичний і соціальний. Кожний із цих рівнів, на думку Смотрицького, логічно випливає $з$ попереднього, створюючи своєрідну ієрархічну послідовність, що пов’язує справжнього пастиря з Богом, з одного боку, й українським суспільством - 3 другого.

Таким чином, головну причину зла він бачить у забутті слова Божого: «Мушу ствердити, що їх самих у дотриманні вказаної вітцем дороги нікчемне недбальство і розпусний непослух подаваному в материнській науці повелінню, а не що інше, спричинили душевну разом з тілесною згнилість, із-за якої ані душа до послуху не здатна, ані тіло до виконання обов'язків не вільне. Із-за недбальства в послусі виникла апатія в навчанні, з того розбухла непокора, а з неї розлилося ледарство» [13, c. 78].

Полеміст уважає, що байдужність до слова Божого пов'язана 3 невіглаством i неосвіченістю служителів церкви, згубними для всієї пастви: «Бо ж деякі із нинішніх розумної отари Христової пастирів ледве чи над нерозумним ослів стадом пастирями бути за гідних виявились» [13, с. 81], - і далі: «Хіба ж той пастирем і вчителем бути може, котрий сам ніколи не вчився? Котрий не знає, що богові винен, а що ближньому своєму?» [13, с. 82].

Інакше кажучи, тільки освічений розум пастиря може зробити його справжнім посередником і провідником волі Божої - «пастирем добрим». Поки ж невігластво стало причиною етичної ущербності ієрархів православної церкви i, як наслідок, моральної деградації всіх станів українського суспільства: «Усі ви єсте корчмарі й купці, в звичаях - домосиди, в розмовах - неуки, в ходінні - лиси облудні, а в одінні вовки хижі», - і далі: «Мудрість ваша, майстерність, розмова - безглузді, даремні i розпусні, забави - непристойні, в них самі ви разом 3 тими, котрі вам наслідують, гините» $[13$, с. 85$]$.

На думку Смотрицького, ключем до розуміння соціальної поведінки «пастиря злого» $\epsilon$ принцип формування православної ієрархії, а саме практика продажу церковних посад, за якої претендент зовсім не зобов'язаний проходити процедуру попереднього іспиту й виборів, що дозволила б виключити негідного кандидата [13, c. 82]. У результаті земельні володіння, які належали церкві, і пов'язані з ними доходи, пожертвування вірян, плата за виконання церковних таїнств - усе це стало доступно будь-якому охочому, готовому заплатити за висвячення [13, с. 82]. Ця практика дозволила фактично ігнорувати вимоги православних канонів i для претендентів на єпископські кафедри, зобов'язаних прийняти чернечий постриг. Тепер «... одні із корчм, інші 3 двору, ті з військ, а дехто 3 поборів, без жодного обрання і без жодного доброго свідчення, за поміччю золота і срібла, до храму 
божого вдерлися» $[13$, с. 82]. За свідченням полеміста, мали місце й зовсім абсурдні ситуації: «Відомо кожному, що у деяких ще материнське молоко на губах не висохнуло, а вже вітцями їх неналежно зробили, ще самі і по складах читати не навчилися, а ми їх проповідувати слово Боже поставили, ще своїми будинками ніколи не керували, а ми їм церковну владу вручили» [17, арк. 25]. Не рідкими були випадки, коли п’ятнадцятирічні підлітки ставали священиками [17, арк. 25].

Підсумок закономірний: аморальність пастирів, яка $\epsilon$ підгрунтям їхньої соціальної поведінки, веде до приниження авторитету православної ієрархії, що, своєю чергою, стимулює розпад церковної структури, яка цементує українське суспільство: «Побачивши це, довірені їм овечатка, нарівні з ними (пастирями - прим. авт.) у недбальство вдалися i, вкладені тягарі 3 рамен своїх скинувши, лінощі возлюбили, що в них і нині з пастирями своїми ганебно гниють...» [13, с. 79-80].

Смотрицький демонструє читачу личини, що приймає «злий» пастир у соціумі, які, урешті-решт, тільки ілюструють особистості й спосіб життя реальних ієрархів і служителів православної церкви: незрілі молодики, нахабні невігласи, непристойні грубіяни, ненажери, премудрі себелюби, безкарні п’яниці, перекірливі самовольці, буйні вітрогони, чванливі бараболки, байдужі підлесники, прокляті святотатці, жадібні скнари, сліпі вожді, недбайливі отці, байдужі пастирі, розпусні священики, несправедливі судді [17, арк. 25].

Як фінальний акорд у викритті «пастирів злих» звучить у «Треносі» плач посиротілої Матері-Церкви за 48 найбільш впливовими православними, у тому числі князівськими родами, вину за відступництво яких Смотрицький цілком покладає на плечі недбайливих пастирів [13, с. 84].

Вишиковуючи опозиційний ряд властивостей, що стосуються характеристики «пастиря доброго», полеміст малює його образ у термінах, що повторюють вищенаведені, але дістали якісно інше етичне звучання: «Бо єпископ має бути... не пишним, не гнівливим, не п'яницею, не забіякою, не хтивим до зиску бридкого, а гостинним, доброчинним, тверезим, справедливим, святим, стриманим, вірним своєму слову, згідному з наукою...» [13, с. 83], - і в іншому місці: «Будьте ж, отож, без вади, тверезими, розумними, поштивими, чистими, гостинними, до навчання здібними, не пропойцями, не забіяками, а скромними, не сварливими, не хтивими, в домі своєму порядними.» [13, с. 76]. Пастирство, яке грунтується на авторитеті етичної досконалості, надасть можливість вилікувати соціальні болячки, що вразили церкву, головна $з$ яких - продаж церковних посад. Однак, ці кроки хоча й необхідні, недостатні для консолідації всього українського суспільства. На думку Смотрицького,

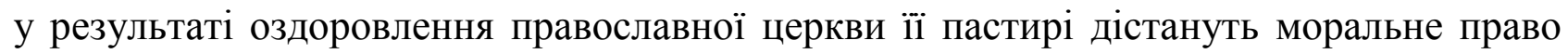
очолити всю українську «націю»: «Таких... потребую тепер синів, ...котрі б не тільки блюзнірцям розпусні уста замкнули, але й своїх, од найвищого до найнижчого, од архієреїв до всіх тих ієреїв, що під владою їхньою перебувають, разом з повіреними урядуванню їхньому людьми, достатньо і відповідно до гідності заслуг їхніх, картали, карали і направляли» [13, с. 74].

У межах цієї концепції полеміст закликає українців до укладення своєрідного «соціального перемир'я», він звертається до всіх станів українського суспільства зі 
словами наставляння й повчання. До «посполитого люду»: «Зверхникам вашим духовним, котрі, на Христовім престолі сівши, тому ж вас, що й Христос, учать, будьте послушні...», - i далі: «Братство любіть, бога бійтесь, королеві честь віддавайте. Слуги, будьте піддані панам у всілякій боязні, не тільки добрим i скромним, але і прикрим» [13, с. 77]. До «зверхників світських»: «Ви, княжата i вельможі, божим судом повірених нам підданих судіте, остерігаючись того, аби тим же судом самі осуджені не були. Не накладайте на них великої данини, відаючи, що і вам пан ваш увесь борг одпустив і чинш за вас заплатив» [13, с. 76], - i далі: «...княжата i зверхники не мають такої влади, аби і зовні і внутрішньо, тобто i світськими і духовними справами по своїй волі керувати могли. Щодо світської влади, то панами вони $\epsilon$ i повелівають. А от щодо духовної - то синами суть $\mathrm{i}$ слухатись повинні» [13, с. 79]. «Ідеальному» суспільству, описаному в «Треносі», повинні відповідати й «ідеальні», а точніше «добрі» пастирі, яким «слуга і пан, вільний і невільник послух оддавати повинен, бо їм ключі царства небесного довірено» [13, с. 79].

Таким чином, ідеї М. Смотрицького стали фактично першою зафіксованою спробою українських інтелектуалів запропонувати свій варіант подальшого розвитку українського суспільства, покликаний забезпечити безперервність процесу формування національної ідеології й політичної традиції в умовах відчутної напруги в міжконфесійних стосунках. Головну роль у цьому процесі полеміст відводить оновленій православній церкві і іiі очікуваним «добрим» пастирям, покликаним не тільки оздоровити саму церкву, але й консолідувати православну спільноту. Незважаючи на виразні мотиви християнського провіденціалізму, у майбутньому ця концепція знайшла цілком мирське застосування, ставши одним 3 елементів ідеологічного підгрунтя дій православних братств i запорізького козацтва, спрямованих на відновлення православної ієрархії не тільки як духовної, але й нової політичної еліти українського народу.

\section{Література:}

1. $\Theta P H N O \Sigma$, to iest Lament iedyney s. powszechney apostolskiey wschodniey cerkwie, z obiasneieniem dogmat wiary. Pierwiey z graeckiego na stowienski, a teraz z stowienskiego na polski przetożony przez Theophila Orthologa, teyże swietey wschodniey cerkwie syna. Wilno, 1610. 218 ark.

2. Paraenesis, abo Napomnienie od w bogu wielebnego Meletiusza Smotrzyskiego, rzeczonego archiepiskopa Połockiego, episkopa Witepskiego y Mscislawskiego, arhimandryte Wilenskiego y Dermanskiego: do przezatnego bractwa Wilenskiego, cerkwie s. Ducha, a w osobie iego, do wshstkiego tey strony narodu Ruskiego uczynione. Krakow. 1629. 96 s.

3. Бабич С. Творчість Мелетія Смотрииького в контексті раннього украӥнського бароко. Львів, 2008. $248 c$.

4. Євсєєва Т. М. Церковна еліта та ї̈ роль у процесі формування політичної самосвідомості в Украӥні. // Український історичний журнал. 1999. № 2. С. 89-104.

5. Квасюк Л. Архетип Церкви-Матері в міфологічних побудовах Мелетія Смотрицького // Наукові записки. Серія «Філософія». Острог, 2008. Вип. 4. С. 55-64.

6. Кралюк П. Мелетій Смотрицький і украйнське духовно-культурне відродження кіния XVI початку XVII cm. Острог, 2007. 208 c. 
7. Кралюк П. М., Щепанський В. В., Якубович М. М. «Тренос» Мелетія Смотрииького в дискурсі західної філософської думки. Київ : КНТ, 2015. 218 с.

8. Майданюк I. Природно-правові тенденції у філософській спадщиині Мелетія Смотрищького // Гілея. Вип. 20. Київ, 2009. С. 265-271.

9. Мицик Ю. Київський патріархат у проектах Петра Могили // Украӥнський історичний журнал. 2007. № 1. С. 57-69.

10. Неменський О. Еволюиія форм ідентичності Мелетія Смотрицького // Біля джерел украӥнського бароко : зб. наук. пращь. Львів : ЛНУ, 2010. С. 41-48.

11. Новые статьи П. Скарги 1590 г. // Памятники полемической литературы. СПб., 1882. Кн. II. C. 527-612.

12. Плохій С. Наливайкова віра: Козаитво та релігія в ранньомодерній Украӥні. Київ : Критика, 2006. 495 c.

13. Рубчак М. Від периферії до иентру: розвиток украӥнської національної самосвідомості у Львові XVI cm. // Філософська і сочіологічна думка. 1993. № 1. С. 96-112.

14. Сенета М. Життєвий і творчий шлях Мелетія Смотрицького в сучасній історіографії // Дрогобищький краєзнавчий збірник. Вип. 14-15. 2011. С. 104-115.

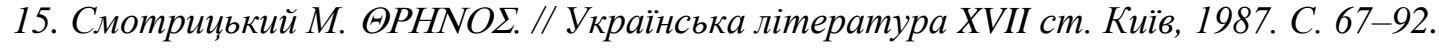

16. Шалашна Н. М. Уявлення Мелетія Смотрищького про державу в контексті процесу формування ранньомодерної української начії // Грані. 2017. Т. 20, № 7. С. 32-38.

17. Яковенко Н. Паралельний світ: Дослідження з історії уявлень та ідей в Украӥні XVI XVII cm. Київ : Критика, 2002. 416 c.

18. Яременко П.К. Мєлєтій Смотрищький. Життя і творчість. Київ, 1986. 160 с.

\section{References:}

1. Babych, S. (2008), Tvorchist' Meletiya Smotryts'koho v konteksti rann'oho ukrayins'koho baroko [Creation of Melety Smotrytsky in the context of the early Ukrainian Baroque], L'viv, 248 p. (in Ukrainian)

2. Yevsyeyeva, T. (1999), "Tserkovna elita ta yiyi rol' u protsesi formuvannya politychnoyi samosvidomosti v Ukrayini» [Church elite and its role in the process of formation of political consciousness in Ukraine], Ukrainian Historical Journal, No 2, pp. 89-104. (in Ukrainian)

3. Kvasyuk, L. (2008), Arxety`p Tserkvy-Materi v mifolohichnykh pobudovakh Meletiya Smotryts'koho [Ahetype of the Church-Mother in the mythological constructions of Melety Smotrytsky], Naukovi zapysky. Seriya «Filosofya», No 4, pp. 55-64. (in Ukrainian)

4. Kralyuk, P. (2007), Meletiy Smotryts'kyy i ukrayins'ke dukhovno-kul'turne vidrodzhennya kintsya XVI - pochatku XVII st. [Melety Smotrytsky and Ukrainian spiritual and cultural revival of the late XVI early XVII century], Ostroh, 208 p. (in Ukrainian)

5. Kralyuk, P., Shchepans'kyy, V., Yakubovych, M. (2012), «Trenos» Meletiya Smotryts'koho v dyskursi zakhidnoyi filosofs'koyi dumky ["Trenos" of Melety Smotrytsky in the discourse of Western philosophical thought], Ostroh, 220 p. (in Ukrainian)

6. Maydanyuk, I. (2009), Pryrodnopravovi tendentsiyi u filosofs'kiy spadshchyni Meletiya Smotryts'koho [Natural law tendencies in the philosophical heritage of Melety Smotrytsky], Hileya 20, pp. 265-271. (in Ukrainian)

7. Mytsyk, Yu. (2007), Kyyivs'kyy patriarkhat u proektakh Petra Mohyly [Kyiv Patriarchate in the projects of Petro Mohyla], Ukrayins 'kyy istorychnyy zhurnal, No1, pp. 57-69. (in Ukrainian)

8. Nemens'kyy, O. (2010), Evolyutsiya form identychnosti Meletiya Smotryts'koho. Bilya dzherel ukrayins'koho baroko [Evolution of the forms of identity of Melety Smotrytsky], pp. 41-48. (in Ukrainian)

9. Novyye stat'i P. Skargi 1590 g. 1882. [New articles by P. Skarga 1590]. Monuments of polemical literature, SPb, Vol. II, pp. 527-612. (in Polish)

10. Plokhiy, S. (2006), Nalyvaykova vira: Kozatstvo ta relihiya v rann'omoderniy Ukrayini [In ammatory Faith: Cossacks and Religion in Early Modern Ukraine]. Krytyka, Kyiv, 495 p. (in Ukrainian) 
11. Rubchak, M. (1993), Vid peryferiyi do tsentru: rozvytok ukrayins'koyi natsional'noyi samosvidomosti u L'vovi XVI st. [From the periphery to the center: the development of Ukrainian national identity in Lviv in the XVI century]. Philosophical and sociological thought No1, pp. 96-112. (in Ukrainian)

12. Seneta, M. (2011), Zhyttyevyy i tvorchyy shlyakh Meletiya Smotryts'koho v suchasniy istoriohrafyi [The life and creative path of Melety Smotrytsky in modern historiography]. Drohobyts'kyy krayeznavchyy zbirnyk, Vol. 14-15, pp. 104-115. (in Ukrainian)

13. Smotryts'kyy, M. (1987), Threnos [Threnos]. Ukrainian literature of the XVII century, Kyiv, pp. 6792. (in Ukrainian)

14. Shalashna, N. (2017), Uyavlennya Meletiya Smotryts'koho pro derzhavu v konteksti protsesu formuvannya rann'omodernoyi ukrayins'koyi natsiyi [Meletiy Smotrytsky's Representation on the State in the Context of the Process of the Formation of the Early Modern Ukrainian Nation]. Grani, Vol. 20, No. 7 , pp. 32-38. (in Ukrainian)

15. Yakovenko, N. (2002), Paralel'nyy svit: Doslidzhennya z istoriyi uyavlen' ta idey v Ukrayini XVI XVII st. [Parallel World: A Study on the History of Ideas and Ideas in Ukraine in the 16th - 17th Centuries], Krytyka, Kyiv, 416 p. (in Ukrainian)

16. Yaremenko, P. (1986), Myelyetiy Smotryts'kyy. Zhyttya i tvorchist' [Melety Smotrytsky. Life and creativity], Kyiv, 160 p. (in Ukrainian)

17. Smotrytskiy, M. (1610), Threnos to iest Lament iedyney ś. Powszechney Apostolskiey Wschodniey Cerkwie, z obiaśnieniem Dogmat Wiary, Wilno, 218 p. (in Polish)

18. Paraenesis, abo Napomnienie od $w$ bogu wielebnego Meletiusza Smotrzyskiego, rzeczonego archiepiskopa Polockiego, episkopa Witepskiego y Mscislawskiego, arhimandryte Wilenskiego y Dermanskiego: do przezatnego bractwa Wilenskiego, cerkwie s. Ducha, a w osobie iego, do wshstkiego tey strony narodu Ruskiego uczynione (1629), Krakow, 96 p. (in Polish)

\section{Georgy Piven}

\section{«GOOD SHEPHERD»: SOCIAL PROJECT OF MELETIUS SMOTRYTSKY}

The article analyzing the treatise by Meletius Smotrytsky's «Threnos» attempts to systematize the views of the author on the role and place of the Orthodox hierarchy in the formation of Ukrainian national ideology and political tradition.

The key idea of the «Threnos» is the idea that social and historical conditions of that time in Ukraine require the appearance of a constellation of prophets or shepherds who are understood by author as spiritual mentors of the people. Their task was to enlighten Ukrainian society and raise its national-religious consciousness. The author of the «Threnos» pays considerable attention to the criticism of the hierarchs of the Ukrainian Orthodox Church when he determines their role in society, therefore, he obviously correlates this role with the expected arrival of the named ecclesiastical and moral leaders, and this gives us reason to suppose that the church should nominate the mentioned spiritual shepherd. Orthodox Church is also versed by Smotrytsky as an authoritative social institution obliged to become the basis for the moral improvement of society and its consolidation before the realization of an external threat.

Smotrytsky pays special attention to the condemnation of the actual culprits of the situation that was formed - in fact, the members of the church hierarchy. He distinguishes three main levels of criticism, which are used to judge the degree of decline of the spiritual shepherd - theological, ethical and social. According to Smotrytsky, each of these levels 
logically follows from the previous one, creating a peculiar hierarchical sequence linking the true shepherd with God, on the one hand, and with the Ukrainian society on the other one.

He sees the main cause of evil in forgetting God's covenants. Smotrytsky believes that the indifference to the testaments of God is connected with the ignorance and incompetence of the ministers of the church, devastating to the whole flock. In other words, only the enlightened mind of the shepherd can make him a real mediator of the will of God - "good shepherd". Meanwhile, the ignorance is the cause of the ethical decline of the hierarchs of the Orthodox Church, and as a result, the moral degradation of all classes of Ukrainian society.

According to Smotrytsky, the key to understanding the social behavior of the «evil shepherd» is the principle of the formation of the Orthodox hierarchy, namely the practice of selling church positions, for which the applicant was not obliged to undergo a preexamination and election procedure, which would exclude a bad candidate. The result is logical: the immorality of shepherds, standing at the basis of their social behavior, leads to the humiliation of the authority of the Orthodox hierarchy, which, in turn, stimulates the collapse of the church structure that should cement Ukrainian society.

Constructing an oppositional set of properties that relate to the characteristics of a «good shepherd», Smotrytsky draws his image in terms that repeat the foregoing, but receive a qualitatively different ethical sound. If pastorship was based on the authority of ethical perfection, it would provide the opportunity to cure the social diseases that struck the church, the main of which is the sale of church positions. However, though necessary, these steps are insufficient to consolidate the entire Ukrainian society. According to Smotrytsky, as a result of the healing of the Orthodox Church, its shepherds will have the moral right to lead the entire Ukrainian «nation».

Thus, the ideas of Meletius Smotrytsky became, in fact, the first fixed attempt of Ukrainian intellectuals to offer their option for the further development of Ukrainian society, designed to ensure the continuity of the process of forming a national ideology and political tradition in conditions of explicit tension in interconfessional relations. The main role in this process is given to the updated Orthodox Church and its expected «good shepherds», who are called not only to improve the Church itself but also to consolidate the Orthodox community. In spite of the expressive motives of Christian providentialism, in the future this concept has found completely secular application, contributing to the ideological justification of the actions of the Orthodox brotherhoods and the Zaporozhian Cossacks, aimed at the restoration of the Orthodox hierarchy as new political elite.

Keywords: orthodox hierarchy, church elite, shepherd, moral perfection.

\section{Георгій Півень}

\section{«ПАСТИР ДОБРИЙ»: СУСПІЛЬНИЙ ПРОЕКТ МЕЛЕТІЯ СМОТРИЦЬКОГО}

Проаналізований трактат Мелетія Смотрицького «Тренос» переслідує дві основні мети: перша - констатація катастрофічного становища української 
православної церкви й усього українського суспільства в цілому, а також аналіз причин цієї національної трагедії; друга - своєрідна політична декларація, що пропонує програму з подолання іiі наслідків, альтернативну унії. Поставленої мети полеміст досягає, використовуючи своєрідний літературний прийом, який можна умовно охарактеризувати як протиставлення двох образів пастиря - реального земного «пастиря злого» і очікуваного ідеального «пастиря доброго».

Ключовою ідеєю автора «Треносу» є думка, що сучасні йому суспільно-історичні умови вимагають появи в Україні плеяди вождів-пророків, духовних наставників народу. Їх завдання - просвітити українське суспільство й піднести його національнорелігійну свідомість. Ураховуючи увагу, яку автор «Треносу» приділяє критиці ієрархів української православної церкви, коли визначає їхню роль у суспільстві, він очевидно співвідносить цю роль з очікуваним приходом названих духовних вождів, й це дає нам підставу припустити, що висунути останніх повинна саме церква. Вона ж мислиться Смотрицьким як авторитетний соціальний інститут, зобов'язаний стати опорою для морального оздоровлення суспільства та його консолідації перед усвідомленням зовнішньої загрози.

У зв'язку з цим особливе місце М. Смотрицький приділяє осудженню дійсних винуватців становища, що утворилося, - власне, церковних ієрархів. Він виділяє три основних рівня критики, за якими судить про ступінь занепаду пастиря богословський, етичний і соціальний. Кожний із цих рівнів, на думку Смотрицького, логічно випливає 3 попереднього, створюючи своєрідну ієрархічну послідовність, що зв'язує справжнього пастиря з Богом, з одного боку, й з українським суспільством - iз другого.

Таким чином, головну причину зла він убачає в забутті слова Божого. Полеміст вважає, що байдужність до слова Божого пов'язана із невіглаством і неосвіченістю служителів церкви, згубними для усієї пастви. Інакше кажучи, тільки освічений розум пастиря може зробити його справжнім посередником і провідником волі Божої «пастирем добрим». Поки ж невігластво стало причиною етичного занепаду ієрархів православної церкви, i, як наслідок, моральної деградації всіх станів українського суспільства.

На думку Смотрицького, ключем до розуміння соціальної поведінки «пастиря злого» $є$ принцип формування православної ієрархії, а саме - практика продажу церковних посад, за якою претендент був зовсім не зобов'язаний проходити процедуру попереднього іспиту й виборів, що дозволило б виключити негідного кандидата.

Підсумок був закономірним: аморальність пастирів, яка є підгрунтям їхньої соціальної поведінки, веде до приниження авторитету православної ієрархії, що, своєю чергою, стимулює розпад церковної структури, яка цементує українське суспільство.

Вишиковуючи опозиційний ряд властивостей, які стосуються характеристики «пастиря доброго», полеміст малює його образ у термінах, що повторюють вищенаведені, але дістали якісно іншого етичного звучання. Пастирство, яке було б засноване на авторитеті етичної досконалості, дасть можливість вилікувати соціальні 
хвороби, що вразили церкву, головна 3 яких - продаж церковних посад. Однак, ці кроки, хоча й необхідні, $є$ недостатніми для консолідації всього українського суспільства. На думку Смотрицького, унаслідок оздоровлення православної церкви їі пастирі дістануть моральне право очолити всю українську «націю».

Таким чином, ідеї М. Смотрицького стали фактично першою зафіксованою спробою українських інтелектуалів запропонувати свій варіант подальшого розвитку українського суспільства, покликаний забезпечити безперервність процесу формування національної ідеології й політичної традиції в умовах відчутної напруги у міжконфесійних стосунках. Головну роль у цьому процесі полеміст відводить оновленої православної церкви та ії очікуваним «добрим» пастирям, покликаним не тільки оздоровити саму церкву, але й консолідувати православну спільноту. Незважаючи на виразні мотиви християнського провіденціалізму, у майбутньому ця концепція знайшла цілком земне застосування, сприявши ідеологічному обгрунтуванню дій православних братств і запорізького козацтва, спрямованих на відновлення православної ієрархії як нової політичної еліти.

Ключові слова: православна ієрархія, церковна еліта, пастир, моральна досконалість.

Piven Heorhii - Senior Lecturer of the Department of Law of the National Aerospace University «Kharkiv Aviation Institute» (Kharkiv).

gylda@ukr.net

Півень Георгій Георгійович - старший викладач кафедри права Національного аерокосмічного університету імені М.С. Жуковського «Харківський авіаційний інститут» (м. Харків).

e-mail: gylda@ukr.net

Надійшла до редакції 14.05.2019. Розглянута на редколегії 14.06.2019.

\section{Рецензенти:}

Доктор філософських наук, професор, декан гуманітарного факультету Національного аерокосмічного університету ім. М. С. Жуковського «ХАI» Копилов В.О.

Доктор філософських наук, професор, професор кафедри філософії Харківського національного університету Повітряних Сил імені Івана Кожедуба Панфілов О.Ю. 